\title{
Low-Dose Cyclophosphamide Synergizes with Dendritic Cell-Based Immunotherapy in Antitumor Activity
}

\author{
Joris D. Veltman, Margaretha E. H. Lambers, Menno van Nimwegen, Sanne de Jong, \\ Rudi W. Hendriks, Henk C. Hoogsteden, Joachim G. J. V. Aerts, and Joost P. J. J. Hegmans \\ Department of Pulmonary Medicine, Erasmus Medical Center Rotterdam, P.O. Box 2040, 3000 CA Rotterdam, The Netherlands \\ Correspondence should be addressed to Joost P. J. J. Hegmans, j.hegmans@erasmusmc.nl
}

Received 30 November 2009; Revised 5 February 2010; Accepted 7 March 2010

Academic Editor: Zhengguo Xiao

Copyright (C) 2010 Joris D. Veltman et al. This is an open access article distributed under the Creative Commons Attribution License, which permits unrestricted use, distribution, and reproduction in any medium, provided the original work is properly cited.

\begin{abstract}
Clinical immunotherapy trials like dendritic cell-based vaccinations are hampered by the tumor's offensive repertoire that suppresses the incoming effector cells. Regulatory $\mathrm{T}$ cells are instrumental in suppressing the function of cytotoxic $\mathrm{T}$ cells. We studied the effect of low-dose cyclophosphamide on the suppressive function of regulatory $\mathrm{T}$ cells and investigated if the success rate of dendritic cell immunotherapy could be improved. For this, mesothelioma tumor-bearing mice were treated with dendritic cell-based immunotherapy alone or in combination with low-dose of cyclophosphamide. Proportions of regulatory T cells and the cytotoxic $\mathrm{T}$ cell functions at different stages of disease were analyzed. We found that low-dose cyclophosphamide induced beneficial immunomodulatory effects by preventing the induction of Tregs, and as a consequence, cytotoxic T cell function was no longer affected. Addition of cyclophosphamide improved immunotherapy leading to an increased median and overall survival. Future studies are needed to address the usefulness of this combination treatment for mesothelioma patients.
\end{abstract}

\section{Introduction}

Malignant mesothelioma (MM) is a cancer arising from mesothelial cells that lines the body's serous cavities (pleural, pericardial, and peritoneal) and the internal organs and is characterized by poor prognosis [1]. Chemotherapy or surgical treatments result in only limited improvements in response and survival. Novel therapeutic strategies are therefore needed. Immunotherapy is a promising but also challenging approach in the treatment of cancer.

Dendritic cells (DCs) are highly mobile antigenpresenting cells, capable of instructing and controlling the activation of NK cells, NKT cells, and B and T lymphocytes [2-4]. Previously we showed that DC-based immunotherapy in a murine MM model leads to protective immunity as well as regression of established tumors [5]. Currently we are investigating DC-based immunotherapy in MM patients. Although DC-vaccines are well tolerated by patients, further optimization is necessary to exploit the full potential of this therapeutic strategy [6].
It is becoming evident that immune suppression plays a crucial role in tumor progressing. Tumors secrete several mediators to recruit and/or activate suppressive cells. Regulatory $\mathrm{T}$ cells (Tregs) are prominent cells in this suppressive environment. These cells are instrumental in allowing a growing cancer to evade immunological attack by impairing $\mathrm{T}$ cell function [7]. Elevated levels of Tregs have been reported in many tumors and their presence predicts for poor survival. We have demonstrated previously the presence of Tregs within the tumors of MM patients [8]. It has also been described that Tregs are increased in the peripheral blood [9] and pleural effusions [10] of these patients.

Recent clinical studies have shown that low-dose cyclophosphamide (CTX) induces beneficial immunomodulatory effects in the context of active or adoptive immunotherapy [11-21]. CTX is widely used to treat various types of malignancies and some autoimmune disorders. It displays either immunosuppressive or immunopotentiating effects, depending on the dosage and the timing of drug administration [22]. Although the mechanisms underlying 
these modulations are not fully understood, low-dose CTX might prevent the development and functionality of the Tregs [23-27].

Van der Most et al. reported that CTX enhances the effectiveness of gemcitabine treatment in murine mesothelioma by reducing the amount of Tregs $[28,29]$. Thereby they underline the immunogenic role of Tregs in the suppression of activated target cells. On the other hand, Jackaman et al. recently stated that Tregs are no potent regulators of antimesothelioma immunity in their murine model and that targeting of these cells will not improve results [30]. Taken together, the role of Tregs in mesothelioma is controversial and whether these cells will influence the outcome of immunotherapy is still unclear.

Here we investigated the effect of CTX on immunosuppression and the combination of CTX and DC-based immunotherapy was studied in a murine MM model. We found that CTX reduced the levels of Tregs and this induced beneficial immunomodulatory effects in the context of DC-based immunotherapy. These results anticipate that antitumor immune responses elicited by DCbased immunotherapy in humans might be improved by simultaneously depleting Tregs using low-dose CTX.

\section{Methods}

2.1. Animals and Cell Lines. Female 6-10 week old BALB/c (H-2d) mice (Harlan, Zeist, The Netherlands) were housed under pathogen-free conditions at the animal care facility of the Erasmus MC, Rotterdam. Experiments were approved by the local Ethical Committee for Animal Welfare and complied to the Guidelines for the Welfare of Animals in Experimental Neoplasia by the United Kingdom Coordinating Committee on Cancer Research (UKCCCR) and by the Code of Practice of the Dutch Veterinarian Inspection. The AB1 cell line, a mouse mesothelioma cell line, was kindly provided by Professor Bruce W.S. Robinson of the Queen Elizabeth II Medical Centre, Nedlands, Australia. The cell line was derived from tumors induced by Wittenoom Gorge crocidolite asbestos injected intraperitoneally into a $\mathrm{BALB} / \mathrm{c}$ mouse [31]. Cells were cultured in RPMI 1640 medium containing $25 \mathrm{mM}$ HEPES, Glutamax, $50 \mu \mathrm{g} / \mathrm{ml}$ gentamicin, and $5 \%(\mathrm{v} / \mathrm{v})$ fetal bovine serum (FBS) (all obtained from GIBCO/Invitrogen, Breda, The Netherlands) in a humidified atmosphere at $37^{\circ} \mathrm{C}$ and $5 \% \mathrm{CO}_{2}$, in air. $\mathrm{AB} 1$ cells were passaged once or twice a week to a new flask by treatment with $0.05 \%$ trypsin, $0.53 \mathrm{mM}$ EDTA in phosphate buffered saline (PBS, all GIBCO/Invitrogen). The cell line was regularly tested and remained negative for mycoplasma contamination.

2.2. Reagents. Cyclophosphamide ([CTX], the generic name for Endoxan) was purchased from Baxter B.V., Utrecht, The Netherlands. A stock solution was prepared by dissolving 1 gram into $50 \mathrm{ml}$ of PBS. It was further diluted in drinking water at a concentration of $0.13 \mathrm{mg} / \mathrm{ml}$.

Every 4 days bottles were carefully examined (volume was determined) and replaced with fresh bottles containing
$100 \mathrm{ml}$ of drinking water or CTX-containing water. No changes in the drinking pattern of mice were observed between tumor-bearing mice with normal water or with CTX-containing drinking water $(+/-3 \mathrm{ml}$ per day per mouse). This equals approximately $20 \mathrm{mg}$ CTX/kg body weight/day and is considered as a low-dose. Dehydration, being one of the points for signs of illness, was routinely checked. No signs of dehydration were observed during experiments except for a few cases with ill health or overt tumor growth.

2.3. Source of Tumor Antigen Derived from AB1 Tumor. AB1 cell line-derived tumor lysate was prepared from $50 \times 10^{6}$ cells suspended per ml PBS. The cell suspension was frozen in liquid nitrogen and disrupted by four cycles of freezethawing followed by sonication for $4 \times 10$ seconds with an amplitude of 10 microns, using a Soniprep 150 ultrasonic disintegrator equipped with a microtip (Sanyo Gallenkamp BV, Breda, The Netherlands) on ice. Cell lysate was aliquoted and stored at $-80^{\circ} \mathrm{C}$.

2.4. Culture Conditions of Bone Marrow-Derived DC Used for Vaccination. DCs were generated with only minor adaptations from a previously described protocol by Lutz [32]. After flushing femurs and tibias and red blood cell lysis, resulting bone marrow cells $\left(2 \times 10^{6}\right)$ were seeded in 100 $\mathrm{mm}$ Petri dishes (day 0) and cultured in $10 \mathrm{ml} \mathrm{DC} \mathrm{Cul-}$ ture Medium [DC-CM]: RPMI 1640 containing glutamaxI (GIBCO/Invitrogen) supplemented with $5 \%(\mathrm{v} / \mathrm{v}) \mathrm{FBS}$, $50 \mu \mathrm{M} \beta$-mercaptoethanol (Sigma-Aldrich), $50 \mu \mathrm{g} / \mathrm{ml}$ gentamicin (Invitrogen), and $20 \mathrm{ng} / \mathrm{ml}$ recombinant murine granulocyte macrophage-colony-stimulating factor [GMCSF, kindly provided by Professor K. Thielemans, Free University Brussels, Belgium]. Cells were cultured at $37^{\circ} \mathrm{C}$ in a humidified atmosphere at $5 \% \mathrm{CO}_{2}$, in air. At day $3,10 \mathrm{ml}$ of fresh DC-CM was added. On day $6,10 \mathrm{ml}$ of each plate was replaced with $10 \mathrm{ml}$ of fresh DC-CM. After 8 days of culture, AB1 cell lysate was added to the DC cultures, to the equivalent of three $\mathrm{AB} 1$ cell-equivalents per DC. After 8 hours, $100 \mu \mathrm{g} / \mathrm{ml}$ LPS (E. coli 026:B6, SigmaAldrich) was added to the culture to allow complete maturation while incubated overnight. The next day, DCs were harvested by gentle pipetting and purified by LympholyteMammal (Cedarlane, Hornby, ON, Canada) density gradient centrifugation, the interphase washed three times in PBS and resuspended at a concentration of $1 \times 10^{6}$ viable cells in $500 \mu \mathrm{l}$ PBS. The quality of the DC preparation was determined by cell-counting, morphologic analysis and cell surface marker expression by flow cytometry, as previously described [5]. DCs $\left(1 \times 10^{6}\right)$ were delivered into the peritoneal cavity of $\mathrm{BALB} / \mathrm{c}$ mice; control mice received $500 \mu \mathrm{l}$ PBS.

\subsection{Treatment with Tumor Lysate-Pulsed DCs and Cyclophos-} phamide on Outcome. Initial experiments were performed to determine the optimal concentration of CTX necessary to reduce Tregs in vivo. Continuous administration via the drinking water of low concentrations ("metronomic") CTX had our preference because a single administration 
of a higher dose or multiple administrations i.p. engenders worse life expectancy as a consequence of peritoneal damage caused by the needle. Approximately $20 \mathrm{mg}$ CTX/kg body weight/day in the drinking water of mice was the optimal concentration for further studies in mice, concentrations below $100 \mathrm{mg} / \mathrm{kg}$ are considered as a low dose. No effect on feeding, body weight, and physical well-being or other side effects were observed at this concentration.

On day $0, B A L B / c$ mice (4 groups each consisting of 6 mice) were inoculated intraperitoneally with $0.5 \times 10^{6} \mathrm{AB} 1$ tumor cells in $500 \mu \mathrm{l} \mathrm{PBS}$. On day 12, 12 mice (2 groups) were vaccinated with $1 \times 10^{6}$ LPS-matured DCs pulsed with AB1 tumor cell line lysate in $500 \mu \mathrm{l}$ PBS. From day 3 till day 10 and/or day 14 till day 21 mice were given drinking water supplemented with $0.13 \mathrm{mg} / \mathrm{ml} \mathrm{CTX}$. Mice were examined daily for evidence of ill health or overt tumor growth. Mice were killed if profoundly ill, according to UKCCCR regulations, and were scored as a death in survival analysis. All mice underwent extensive autopsy.

2.6. Immunohistology on Tumor Biopsies. Tumor biopsies were embedded in Tissue-Tek II optimum cutting temperature medium (Miles, Naperville, IL, USA), snap-frozen, and stored at $-80^{\circ} \mathrm{C}$. Tissue sections $(6 \mu \mathrm{m})$ were cut on an HM-560 cryostat (Microm, Heidelberg, Germany) and immunostaining was carried out using a rat antimouse Foxp3 antibody (eBioscience [\#14-5773], San Diego, CA, USA). Binding of antibody was detected using alkaline phosphatase- (AP-) conjugated goat antirat (Sigma-Aldrich Chemie B.V.). Naphtol-AS-MX-phosphate $\left(0.30 \mathrm{mg} \cdot \mathrm{mL}^{-1}\right.$; Sigma-Aldrich Chemie B.V., Zwijndrecht, the Netherlands) and new fuchsine $\left(160 \mathrm{mg} \cdot \mathrm{mL}^{-1}\right.$ in $2 \mathrm{M} \mathrm{HCl}$; ChromaGesellschaft, Köngen, Germany) were used as substrate. The specificity was checked using a protein concentrationmatched nonrelevant rat antibody and PBS. Double staining of Foxp3 and CD8 was performed using the AP-conjugated goat antirat followed by rabbit antiphycoerythrin (AbD Serotec, Düsseldorf, Germany) followed by incubation with horseradish peroxidase- (HRP-) conjugated swine antirabbit. Naphtol-AS-MX-phosphate and $1 \mathrm{mM}$ Fast Blue substrate were used as substrate for AP, and NovaRed was used as substrate for HRP, according to the manufacturer's instructions (Vector, Burlingame, CA, USA). Foxp3 and phycoerythrinlabeled antimouse CD8 (BD Biosciences, San Jose, CA, USA) were both used at a dilution of $1: 10$. Signals were captured on a Leica microscope (Leica Microsystems B.V., Rijswijk, The Netherlands).

2.7. Preparation of Lymphocytes from Lymphoid Organs or Blood. Lymphocytes were collected from the spleens, lymph nodes, and blood of mice from each group. Briefly, spleens and lymph nodes were aseptically removed and mechanically dispersed in cold PBS. Cells suspensions were filtered through a $100 \mu \mathrm{m}$ nylon mesh cell strainer (BD Biosciences, Bedford, MA, USA). Resulting suspensions and blood were depleted of erythrocytes by density gradient centrifugation, washed twice with $\mathrm{PBS}+2 \% \mathrm{BSA}$, and resuspended at a concentration of $1 \times 10^{6}$ cells $/ \mathrm{ml}$ for flow cytometric analysis.
2.8. Flow Cytometry. The following antimouse antibodies were used: fluorescein isothiocyanate- (FITC-) conjugated anti-CD4 (1:800), anti-CD19 $(1: 200)$, phycoerythrin- (PE)-conjugated anti-CD3 $(1: 25)$, anti-CD25 (1:200) (all from BD Biosciences), allophycocyanin- (APC)conjugated anti-Foxp3 (1:25) (eBioscience), and appropriate isotypematched controls.

For cell surface marker staining, cells were washed with FACS-wash $\left(0.05 \% \mathrm{NaN}_{3}, 2 \%\right.$ BSA in PBS) and Fc $\gamma$ II/III receptor blocking was performed using antimouse 2.4G2 antibody ( $1: 100$; kindly provided by L. Boon, Bioceros, Utrecht, The Netherlands) for 15 minutes on ice. After the blocking procedure, properly diluted antibodies for cell surface staining were added into each sample and placed on ice for 30 minutes protected from light. After two additional washes with FACS-wash, Fix/Perm buffer (eBiosience) was added and cells were incubated for 1 hour at $4^{\circ} \mathrm{C}$ in the dark. Cells were washed twice with Perm buffer. Intracellular staining was performed for Foxp3 according to the manufacturer's instructions (eBioscience). After blocking for 15 minutes with blocking antibody 2.4G2, properly diluted APC-conjugated Foxp3 antibody in Perm buffer was added and incubated for 30 minutes on ice protected from light. After washing the cells twice with Perm buffer, cells were washed with FACS-wash and measured. Data acquisition was performed by flow cytometry (LSR II; BD Biosciences) and data analysis was performed with FlowJo software (Tree Star, Inc.).

2.9. Coculture of Tregs and Activated Splenocytes. Splenocytes obtained from tumor-bearing mice were stained for CD3, $\mathrm{CD} 4, \mathrm{CD} 8$, and CD25. Four colour sample sorting was done on a FACS ARIA (BD Biosciences). Tregs were defined as $\mathrm{CD}^{+}{ }^{+} \mathrm{CD} 4{ }^{+} \mathrm{CD} 25^{+ \text {bright }}$ cells and sorted with a purity $>90 \%$ as determined by intracellular staining on Foxp3 expression. Splenocytes of DC-treated mice were cocultured with sorted Treg cells at different ratios. Splenocytes were restimulated for 4 hours using anti-CD3 and stained with $\mathrm{mAbs}$ directed against CD3, CD8, intracellular Granzyme B, and IFN- $\gamma$.

2.10. Statistical Analysis. Data are expressed as mean \pm SD. Comparisons between groups were made using the MannWhitney U-test for independent samples. A two-tailed $P$ value $<.05$ was considered significant. Data presented as a percentage of tumor-free animals were analyzed with Kaplan-Meier survival curves, using the log-rank test to determine statistical significance.

\section{Results}

3.1. Regulatory T Cells in the Mouse Mesothelioma Model. The mesothelioma mouse model described in our previous study was used to examine the presence of $\mathrm{CD} 4{ }^{+} \mathrm{CD} 25^{+} \mathrm{Foxp}^{+} \mathrm{T}$ cells in tumor progression [8]. In this protocol, $\mathrm{BALB} / \mathrm{c}$ mice were intraperitoneally (i.p.) injected with a lethal dose of $0.5 \times 10^{6} \mathrm{AB} 1$ tumor cells or $500 \mu \mathrm{l} \mathrm{PBS}$ as control. First signs of terminal illness (typically formation of ascites, ruffled hair, or marked loss of 
condition) appeared between 20 days and 30 days in tumor cell inoculated mice. Mice were sacrificed and subjected to extensive autopsy. All tumor inoculated mice showed solid tumor formation within the peritoneal cavity. The nature of these solid tumors varied from small nodules spreading throughout the mesentery and peritoneal lining to a single large mass. Tumor tissue, blood, spleen, and lymph nodes were collected from tumor-bearing mice for further analyses at day 10 or at first signs of terminal illness. No tissue abnormalities or formation of tumors could be detected in naive (PBS treated) mice.

The presence of Tregs in mesothelioma tissue sections at day 10 was analyzed by immunohistochemistry for the phenotypic evidence of the transcription factor Foxp3, a hallmark of naturally arising $\mathrm{CD} 4^{+} \mathrm{CD} 25^{+}$Treg cells [3337]. Stainings confirmed that mouse tumor tissue obtained from $\mathrm{AB} 1$ inoculated mice contained significant amounts of Foxp $3^{+}$regulatory $\mathrm{T}$ cells, consisting with previous findings in human mesothelioma tissue [8]. Foxp3-expressing cells were located in the proximity of the tumor areas (Figure 1(a)). Double staining showed that the presence of these cells was occasionally in the vicinity of $\mathrm{CD}^{+} \mathrm{T}$ cells, suggesting their possible direct suppressive role in antitumoral responses (Figure 1(b)).

We then examined the blood and peripheral lymphoid organs for the presence of Tregs, determined by CD4, CD25, and Foxp3 positive expression using flow cytometry. In peripheral blood of control mice, the mean proportion of Treg cells was $4.9 \%$ of all $\mathrm{CD}^{+}{ }^{+} \mathrm{T}$ cells. The percentage increased in the blood to $6.1 \%$ ten days after the inoculation of $\mathrm{AB} 1$ tumor cells (Figure 1(c)). Also the $\mathrm{CD} 4{ }^{+} \mathrm{CD} 25^{+} \mathrm{Foxp}^{+}$Tregs were increased in the lymph nodes from $8.9 \%$ to $11.5 \%$ of the total $\mathrm{CD}^{+} \mathrm{T}$ cell population in tumor-bearing mice (Figure 1(d)). In the splenocytes from tumor-inoculated mice, the presence of Foxp $3^{+}$Tregs increased to $11 \%$ compared to $9 \%$ in the control group treated with PBS alone (data not shown).

To determine the impact of a growing tumor on Tregs, the percentage of Foxp $3^{+} \mathrm{T}$ cells in the draining lymph nodes was measured. Total weight of excised tumor tissue and the percentage of Tregs in the draining lymph nodes of corresponding mice are depicted in Figure 1(e). At ten days after $\mathrm{AB} 1$ inoculation $(n=5)$, the weight of the total tumor mass collected varied from 0.1 gram to 1 gram, or larger (1.5 to 2.1 gram) when mice showed evidence of ill health or overt tumor growth $(n=3)$.

In conclusion, Tregs were found within the tumor area and increased proportions of Tregs were found in the tumorbearing mice. Moreover we show a significant increase in the proportion of Tregs that correlates with tumor burden $(P=$ .0039).

3.2. Reduction of Tregs Improves Cytotoxic T Cell Function In Vivo. To demonstrate that cytotoxic $\mathrm{T}$ cell function is inhibited by Tregs, the intracellular expression of granzyme $\mathrm{B}$ and IFN- $\gamma$ in activated $\mathrm{CD}^{+} \mathrm{T}$ cells was measured. Tregs from tumor-bearing mice were isolated from spleen. These $\mathrm{CD} 4^{+} \mathrm{CD} 25^{+} \mathrm{T}$ cells were then added in different ratios to the activated splenocytes isolated from DC-treated mice. Intracellular granzyme B expression by $\mathrm{CD}^{+} \mathrm{T}$ cells decreased in the fractions containing high amounts of $\mathrm{CD}^{+}{ }^{\mathrm{CD}} 25^{+} \mathrm{T}$ cells. The same was observed for the IFN- $\gamma$ expression (Figure 2). When $\mathrm{CD} 4{ }^{+} \mathrm{CD} 25^{+} \mathrm{T}$ cells are present in a ratio higher than $1: 100$, the function of $\mathrm{CD}^{+} \mathrm{T}$ cell is impaired.

Taken together, these data provide evidence that the addition of Tregs leads to impaired CD8 T cell activation.

\subsection{Effects of Low-Dose Cyclophosphamide on the T and B Cell} Populations. To examine the immunomodulating effects of CTX on Tregs, BALB/c mice were inoculated i.p. with $0.5 \times$ $10^{6} \mathrm{AB} 1$ mesothelioma tumor cells and given drinking water with or without CTX. After 10 days peripheral blood and spleen were analyzed. Metronomic CTX treatment resulted in a significant decrease in the proportions of $\mathrm{CD} 19^{+} \mathrm{B}$ cells and an increase of $\mathrm{CD}^{+} \mathrm{T}$ cells (Figures $3(\mathrm{a})$ and $3(\mathrm{~b})$ ), in agreement with reports by others [13]. In contrast to the significant increase in the proportions of total $\mathrm{CD}^{+} \mathrm{T}$ cells, we observed a significant reduction in the fractions of Foxp $3^{+}$ T cells (Figures 3(a) and 3(b)).

In summary, these data show that metronomic administration of low-dose CTX has a strong immune-modulating effect in vivo, causing a shift in ratio between $\mathrm{CD} 19^{+} / \mathrm{CD}^{+}$ cells. Addition of CTX to drinking water of mice leads to a significant increase in the proportion of $\mathrm{CD}^{+} \mathrm{T}$ cells in the peripheral blood and the spleen, whereas the proportion of Tregs is reduced.

\subsection{CTX Improves Suboptimal Dc-Based Immunotherapy.} Next, we then investigated if combining CTX and DC vaccination enhanced the efficacy of the DC treatment as an antitumor treatment. In contrast to optimal DC-treatment protocols (as described by Hegmans et al. [5]), DCs are given at a relative late time point (day 12) in order to achieve suboptimal survival of DC-treated mice. Twelve days after i.p. tumor cell inoculation, mice were vaccinated with $1 \times 10^{6}$ LPS-matured DCs pulsed with AB1 tumor lysate. Mice that received CTX had an increased survival, as seen in our earlier experiments, compared to untreated mice.

When mice were given drinking water supplemented with $0.13 \mathrm{mg} / \mathrm{ml}$ CTX from day 3 till day 10 and day 14 till day 21 , an increased survival was measured. However, the combination of DC-based immunotherapy and CTX administration significantly improved survival compared to DCbased immunotherapy $(P<.0035)$ or CTX administration alone $(P<.0056)$ (Figure 4$)$.

Therefore, we conclude that CTX is a powerful tool to optimize suboptimal DC-based immunotherapy. Although CTX alone also improves survival, the combination of both was significantly better.

\subsection{Long-Term Administration of CTX Improves Survival} Compared to Pre- or Postlmmunotherapy Treatment. It has been reported that the timing of CTX administration is critical $[38,39]$, therefore we investigated the consequences of administration at different time points. To evaluate the effect of timing of CTX administration, mice were divided 

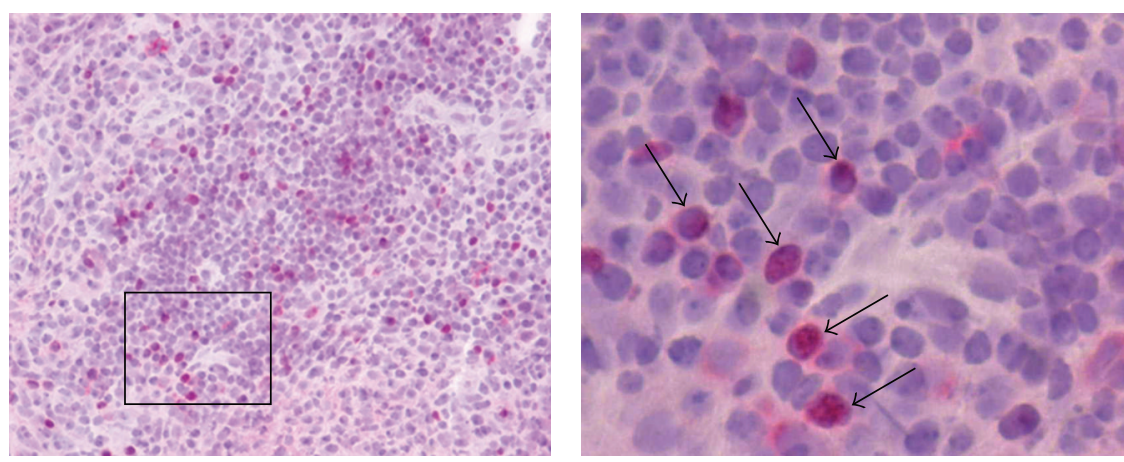

(a)

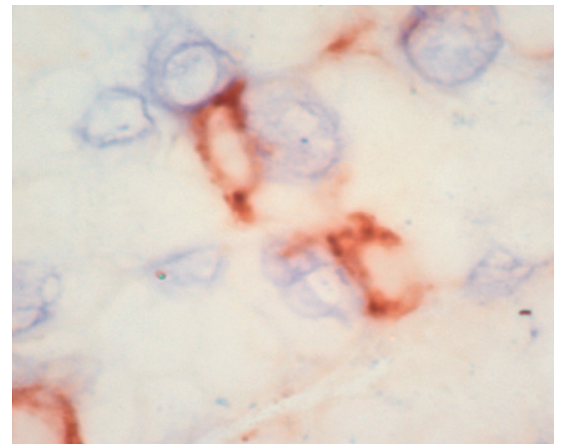

(b)

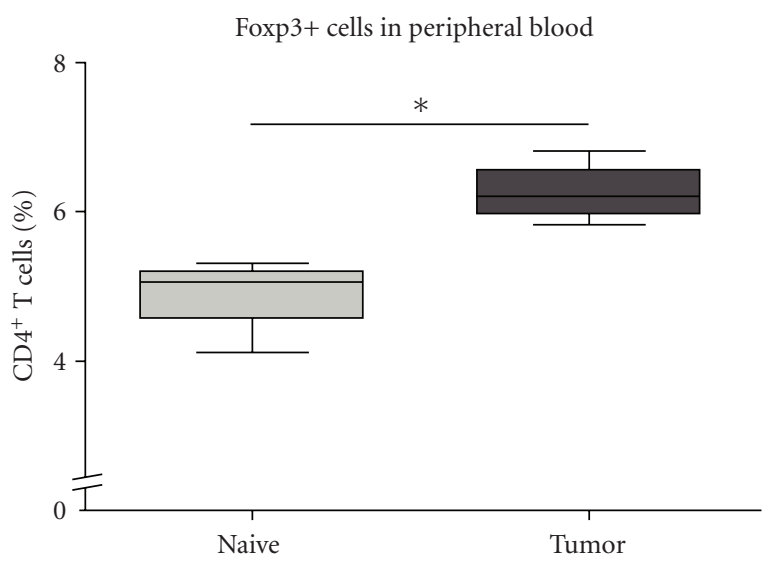

(c)

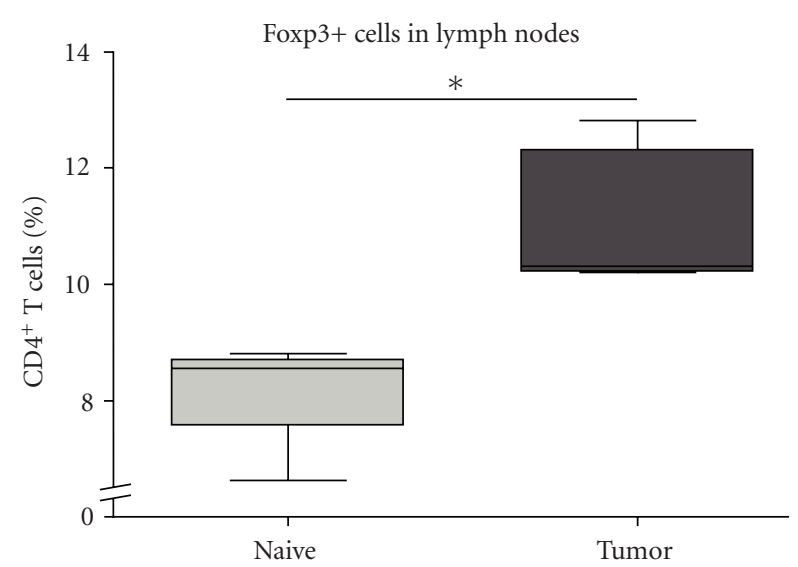

(d)

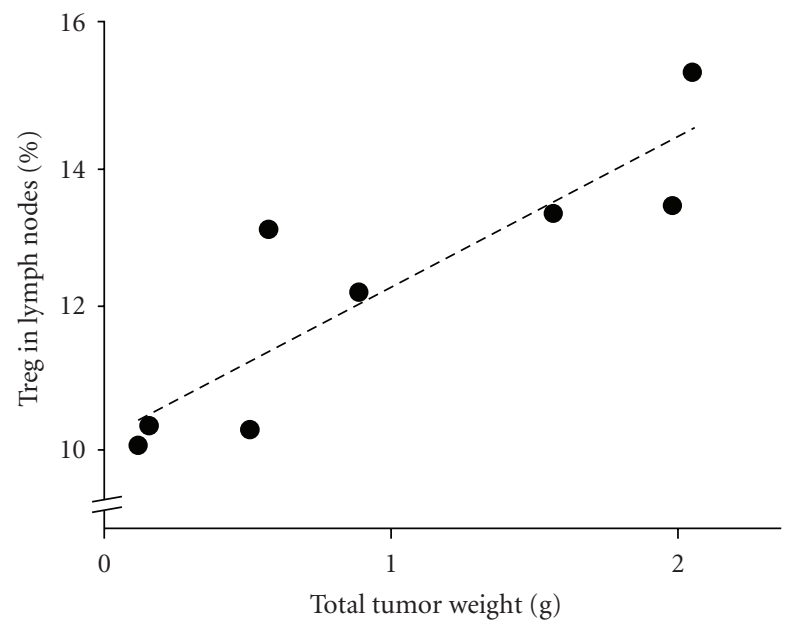

(e)

FIGURE 1: Increase in the proportion of regulatory T cells in a murine model for mesothelioma. (a) Left: The transcription factor Foxp3, a hallmark of naturally arising $\mathrm{CD} 4{ }^{+} \mathrm{CD} 25^{+}$Tregs, was expressed inside the tumor (red staining). Cells were counterstained with haematoxylin. [Magnification 200×] Right: A higher magnification $(400 \times)$ shows the appearance of Foxp3 ${ }^{+}$cells as indicated by arrows. (b) Tregs (blue staining) were occasionally present in the near vicinity of $\mathrm{CD}^{+}$cells (red staining) [Magnification $1000 \times$ ]. (c) and (d) Percentage of Tregs (defined as $\mathrm{CD}_{4}^{+} \mathrm{CD} 25^{+}$Foxp $^{+}$cells) from total $\mathrm{CD}^{+} \mathrm{T}$ cells in the peripheral blood and draining lymph nodes is significantly higher at day 10 in tumor-bearing mice compared to healthy mice as observed by flow cytometry. (e) A positive correlation was found between the total tumor weight and the percentage of Tregs, measured in the lymph nodes of tumor-bearing mice. Five mice were euthanized at day 10 (tumor weight varied from 0.1 gram to 1 gram) and three mice at stage with ill health (tumor weight 1.5 to 2.1 gram). Correlation coefficient of the trend line ( $R$-squared) is 0.780 ( $P$ value is .0039). 


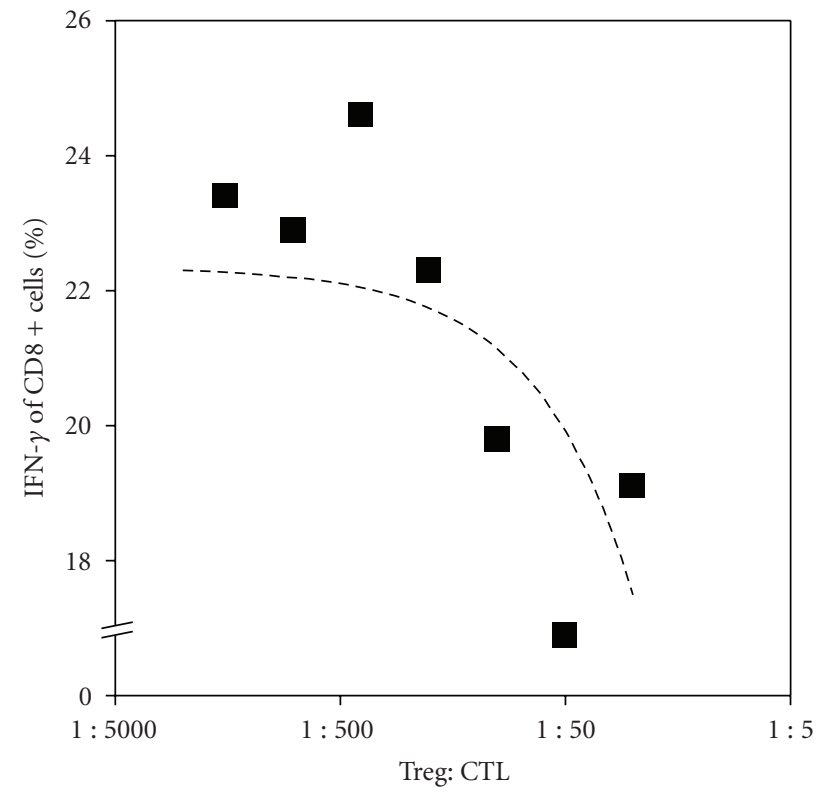

(a)

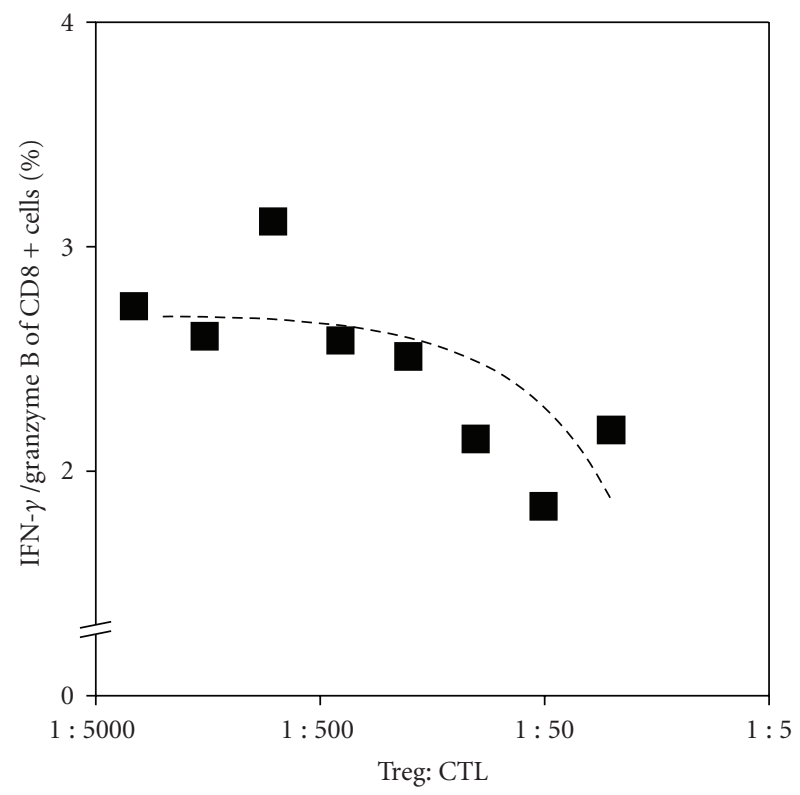

(b)

FIgure 2: Tregs inhibit CTL function in vitro. (a) Activated splenocytes from DC-treated mice were cocultured with CD4 $4^{+} \mathrm{CD} 25^{+}$Foxp $3^{+}$ cells (purified from tumor-bearing mice) in different ratios. The percentage of intracellular IFN- $\gamma$ of CD8+ cells was measured using flow cytometry. And (b) the percentage of intracellular IFN- $\gamma$ and granzyme B expression was measured using FACS. A reduction in the IFN- $\gamma$ and granzyme B expression was found especially in those fractions where increasing doses of Treg were added to the CD8 ${ }^{+} \mathrm{T}$ cells.
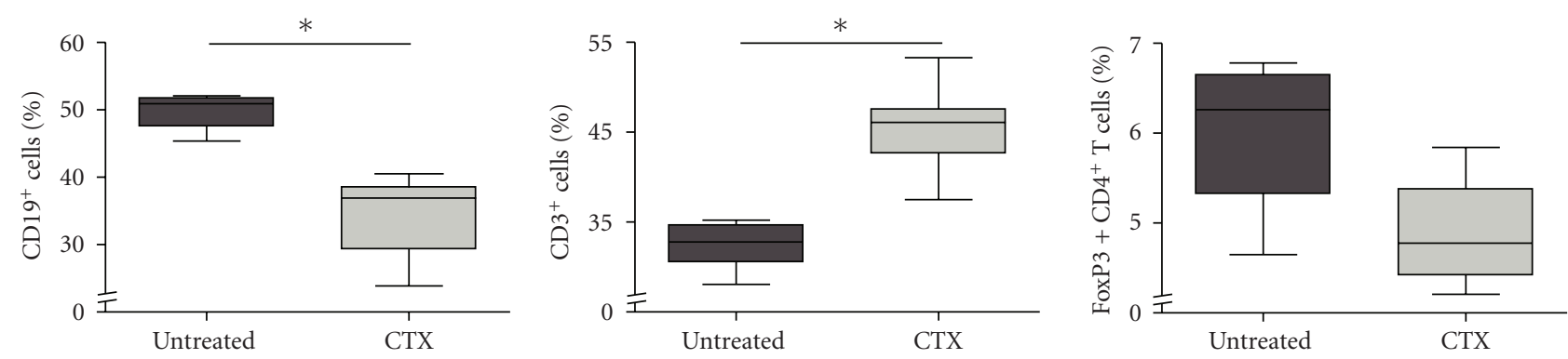

(a) Peripheral blood
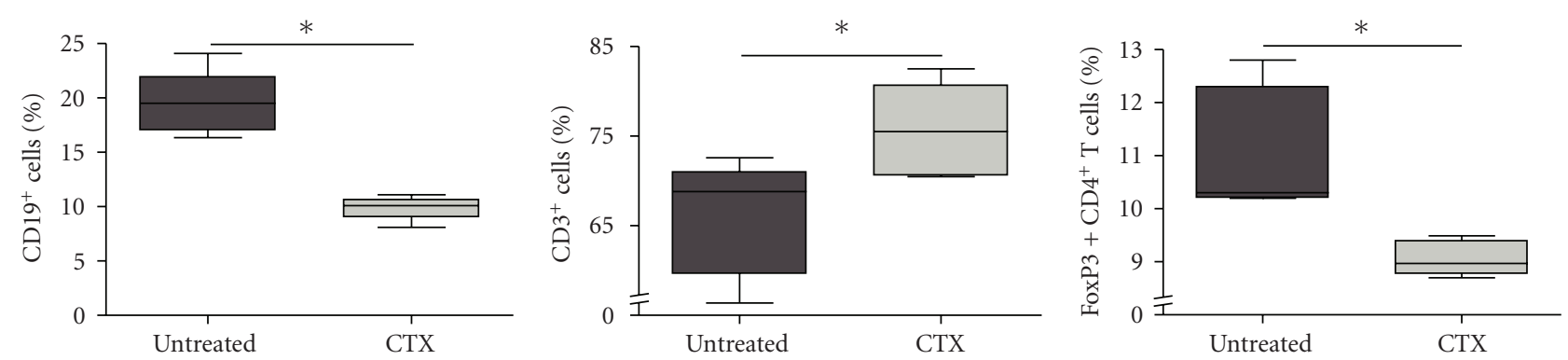

(b) Spleen

FIGURE 3: CTX influences lymphocyte subsets in peripheral blood and draining lymph nodes of tumor-bearing mice. (a) The percentage of $\mathrm{CD} 19^{+}$cells was significantly decreased $(P<.05)$ in CTX-treated tumor-bearing mice. $\mathrm{CD}^{+}$cells were significantly increased $(P=.0325)$ in the peripheral blood of CTX-treated tumor-bearing mice compared to untreated tumor-bearing mice. (b) CD19 ${ }^{+}$cells were significantly decreased $(P<.05)$ while $\mathrm{CD}^{+}$cells were significantly increased $(P<.05)$, while the percentage of CD $4^{+} \mathrm{CD} 25^{+}$Foxp $3^{+}$cells was significantly decreased $(P<.05)$ in the splenocytes of CTX-treated mice compared to untreated tumor-bearing mice. 


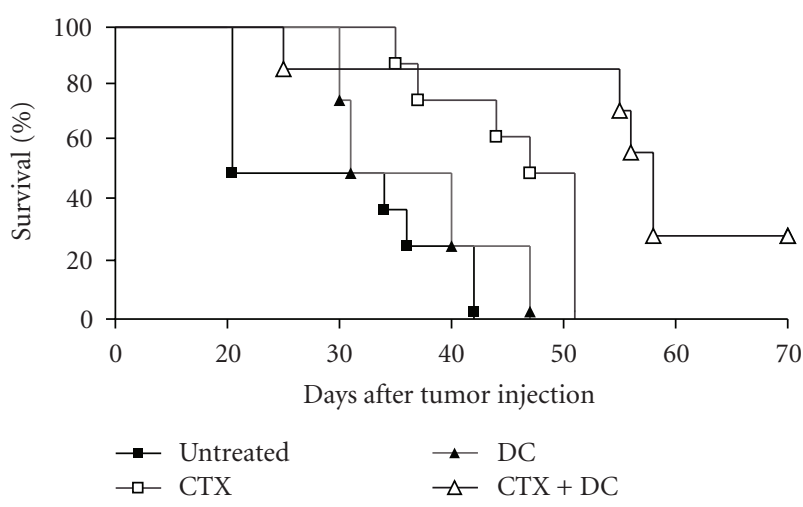

FIGURE 4: CTX combined with DC-based immunotherapy prolongs survival. Kaplan-Meier survival plot showing the effect of the combination of CTX and DC-based immunotherapy. Mice were given drinking water supplemented with $0.13 \mathrm{mg} / \mathrm{ml}$ CTX from day 3 till day 10 and day 14 till day 21. Tumor-lysate-pulsed DCs were given at day 12. Survival significantly improved when CTX and DC-based immunotherapy were combined compared to DCbased immunotherapy $(P=.0035)$ or CTX administration alone $(P=.0056)$. Each group contained 8 mice.

into three groups, receiving low-dose CTX before (day 3 till 10) or after (day 14 till 21) immunotherapy or longterm CTX (day 3 till 10 and day 14 till 21). Mice were treated with DC-immunotherapy on day 12 . No significant differences were found between the groups (before $[P=$ .37], after treatment $[P=.84])$. However long-term CTX administration may prolong the survival beneficial since no side effects of this low dose were observed (Figure 5).

\section{Discussion}

Cancer immunotherapy attempts to harness the exquisite power and specificity of the immune system to recognize and destroy tumor cells or to prevent tumor recurrence. The finding that some patients with malignant pleural mesothelioma (MM) have tumors that regress spontaneously [40-43] or respond to immunotherapy [44-48] suggests that the immune system can generate antitumor reactivity under specific circumstances [41, 49].

DCs are extremely potent antigen-presenting cells specialized in inducing activation and proliferation of lymphocytes, which are essential for tumor killing [50]. Patient's own DCs can be used to present tumor-associated antigens and thereby generate tumor-specific immunity $[3,4]$. Previously we used the mesothelioma mouse model to examine the impact of dendritic cell immunotherapy [5]. For malignant mesothelioma, as for most other cancer types, only a few tumor-associated antigens (TAAs) are known. These antigens are not expressed on the membranes of all tumors and therefore less suitable for antigen source for DC pulsing. Furthermore, none of these TAAs have been evaluated as a source of peptides to pulse DC or in a cancer vaccine trial. Tumor lysate priming strategies are advantageous in providing the full antigenic repertoire of the tumor and, particularly, unique individual tumor antigens, which will

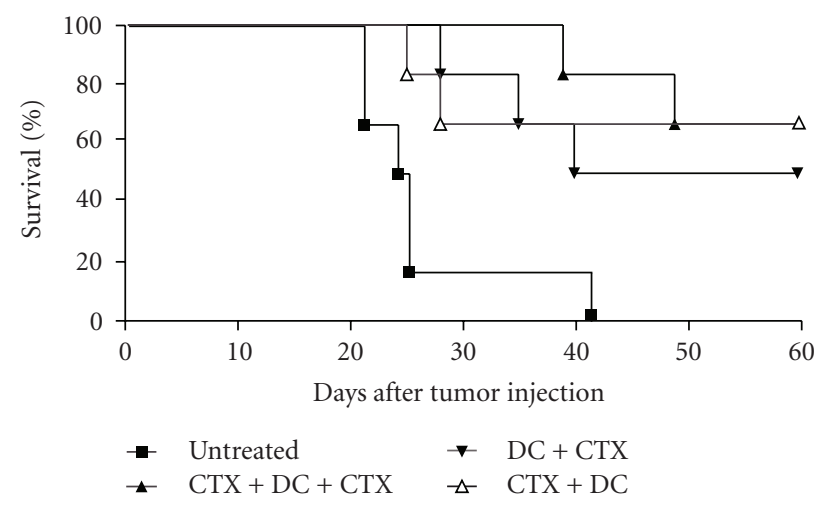

FIgURE 5: Long-period administration of CTX improves survival compared to pre- or post-immunotherapy treatment. Mice were divided into four groups ( $n=6$ per group) and inoculated with a lethal dose of $\mathrm{AB} 1$ tumor cells on day 0 . Mice received low-dose CTX before (day 3 till 10) or after (day 14 till 21) immunotherapy or metronomic dosed CTX (day 3 till 10 and day 14 till 21). Groups 2, 3, and 4 were treated with DC-immunotherapy on day 12. Group 1 functioned as a tumor control group and did not receive any treatment. Administration of metronomic dosed CTX was not significantly better than CTX treatment before $(P=.840)$ or after $(P=.454)$ immunotherapy. However, the combination of CTX and immunotherapy was significantly better than no treatment (CTX before immunotherapy compared to untreated $P=.0081$, CTX after immunotherapy compared to untreated $P=.0147$, metronomic dosed CTX and immunotherapy compared to untreated $P=.0018$ ).

theoretically decrease the ability of tumors to evade the immune response by downregulation of a single antigen. Therefore, DCs were pulsed with autologous total tumor lysate fractions prepared by freeze thawing and sonication of AB1 tumor cells. Mice receiving tumor lysate-loaded DCs developed a protective antitumor immunity when animals were vaccinated before tumor inoculation. They showed no signs of tumor growth even after 3 months and after repeated injection of tumor cells (2nd tumor challenge). MM had a better outcome when DCs were injected early in tumor development indicating that tumor load played an important role in survival.

There are multiple levels to explain the limited benefit from DC vaccinations in mice with high tumor load. It has been suggested that immune suppression by tumor-derived factors is one of the main reasons for immunotherapy failure in general $[7,51]$. Tumors escape immune recognition by attracting immune suppressive cells like Treg cells and myeloid-derived suppressor cells. Others and we have shown that mesothelioma cells are potent sources of a number of cytokines (e.g., IL-6, IL-8, VEGF, GRO, and RANTES) that might directly suppress immune activating cells, like DCs and/or recruit suppressive cells and thereby abolish an efficient immune response [8]. It has become evident that while protecting the host against cancer development, the immune cells also promote the emergence of tumors with reduced immunogenicity leading to a complex interplay of tumor growth and tumor regression mechanisms. 
Like in human mesothelioma biopsies, a growing $\mathrm{AB} 1$ tumor in vivo contains significant amounts of $\mathrm{CD} 4^{+} \mathrm{CD} 25^{+} \mathrm{Foxp}^{+}$regulatory Tcells, which were previously shown to promote tumor progression in other cancer models. Exact mechanisms are not yet fully understood; however one of the mechanisms by which Tregs can abolish the effectiveness of immunotherapy may be by their capacity to produce granzyme B. This can lead to killing of cytotoxic $\mathrm{T}$ cells [52-54]. Depletion of Tregs by using a blocking antiCD25 antibody (PC61), capable of specifically binding to the IL- 2 receptor $\alpha$-chain, led to an increased survival in mice; however, this depleting antibody is not suitable for human clinical use. Cyclophosphamide (CTX) is an alkylating cytotoxic cancer drug that, depending on its dose and timing of administration, has been used as a chemotherapeutic and disease-modifying agent or to enhance immune responses [14, 26, 27, 55-57]. Reports dating from the 1980s have shown that under some conditions low-dose CTX can potentiate antitumor immunity in mouse models [55]. Recently it has been suggested that this effect is caused by the depletion of Tregs [39]. Reductions in the amount of Tregs by using CTX were also found in mesothelioma [28]. In addition, Van der Most et al. showed that the combination of CTX and gemcitabine eradicates established murine mesothelioma whereas single treatment with gemcitabine did not lead to total tumor regression [29]. However the benefit of combining Treg depletion with DC-based immunotherapy for mesothelioma was not established till now.

$\mathrm{CD}^{+}{ }^{+} \mathrm{CD} 25^{+} \mathrm{Foxp}^{+}{ }^{+}$regulatory $\mathrm{T}$ cells comprise between 5 and $10 \%$ of the total $\mathrm{CD} 4^{+}$population in the blood of mice, and are important in controlling tolerance to self-antigens and thereby maintain immune system homeostasis $[54,58]$. We found that the prevalence of Tregs increases in tumorbearing mice in the tumor, peripheral blood, and lymph nodes (Figures 1 and 3) as compared with normal controls. Prolonged, lower-dose ("metronomic") CTX inhibits the rise of Tregs (Figure 3). This effect augments the efficacy of dendritic cell-based immunotherapy (Figures 4 and 5). DCbased immunotherapy leads to an increase in survival that is further improved by depleting Treg cells.

\section{Conclusion}

We found that CTX is an applicable agent to reduce the proportion of Tregs in tumor-bearing mice. In addition, we showed that combining CTX and DC-based immunotherapy significantly prolongs the mean and overall survival in murine model for mesothelioma. We anticipate that CTX allows the host immune system to overcome the immunosuppressive mechanisms of Tregs, thereby allowing for a more complete and robust antitumor immune response initiated by DC-vaccination that is paramount to eliminate the tumor in vivo. Our findings suggest that CTX may also potentiate the immunogenicity of DC-immunotherapy in mesothelioma patients. In fact, these findings now form the basis of a new trial aiming the depletion of Tregs by CTX in combination with DC-based immunotherapy as a multimodality treatment in mesothelioma patients after chemotherapy.

\section{Non-Standard Abbreviations}

\author{
CTL(s): Cytotoxic T lymphocyte(s) \\ CTX: Cyclophosphamide \\ MM: Malignant mesothelioma \\ DC(s): Dendritic cell(s) \\ Treg(s): Regulatory T cell(s).
}

\section{Conflict of Interest}

None of the listed authors on this paper had any contact with people or organizations that could inappropriately influence (bias) their work.

\section{Acknowledgments}

This study was funded by the "Stichting Asbestkanker Rotterdam" and Stichting Coolsingel.

\section{References}

[1] B. W. S. Robinson, A. W. Musk, and R. A. Lake, "Malignant mesothelioma," The Lancet, vol. 366, no. 9483, pp. 397-408, 2005.

[2] J. Banchereau and R. M. Steinman, "Dendritic cells and the control of immunity," Nature, vol. 392, no. 6673, pp. 245-252, 1998.

[3] J. Banchereau and A. K. Palucka, "Dendritic cells as therapeutic vaccines against cancer," Nature Reviews Immunology, vol. 5, no. 4, pp. 296-306, 2005.

[4] R. M. Steinman and M. Dhodapkar, "Active immunization against cancer with dendritic cells: the near future," International Journal of Cancer, vol. 94, no. 4, pp. 459-473, 2001.

[5] J. P. J. J. Hegmans, A. Hemmes, J. G. Aerts, H. C. Hoogsteden, and B. N. Lambrecht, "Immunotherapy of murine malignant mesothelioma using tumor lysate-pulsed dendritic cells," American Journal of Respiratory and Critical Care Medicine, vol. 171, no. 10, pp. 1168-1177, 2005.

[6] C. G. Figdor, I. J. M. de Vries, W. J. Lesterhuis, and C. J. M. Melief, "Dendritic cell immunotherapy: mapping the way," Nature Medicine, vol. 10, no. 5, pp. 475-480, 2004.

[7] S. Sakaguchi, N. Sakaguchi, J. Shimizu, et al., "Immunologic tolerance maintained by $\mathrm{CD} 25^{+} \mathrm{CD} 4^{+}$regulatory T cells: their common role in controlling autoimmunity, tumor immunity, and transplantation tolerance," Immunological Reviews, vol. 182, pp. 18-32, 2001.

[8] J. P. J. J. Hegmans, A. Hemmes, H. Hammad, L. Boon, H. C. Hoogsteden, and B. N. Lambrecht, "Mesothelioma environment comprises cytokines and T-regulatory cells that suppress immune responses," European Respiratory Journal, vol. 27, no. 6, pp. 1086-1095, 2006.

[9] F. Meloni, M. Morosini, N. Solari, et al., "Foxp3 expressing $\mathrm{CD}^{+} \mathrm{CD}^{2} 5^{+}$and $\mathrm{CD}^{+} \mathrm{CD} 8^{-} \mathrm{T}$ regulatory cells in the peripheral blood of patients with lung cancer and pleural mesothelioma," Human Immunology, vol. 67 , no. 1-2, pp. 1$12,2006$.

[10] P. DeLong, R. G. Carroll, A. C. Henry, et al., "Regulatory T cells and cytokines in malignant pleural effusions secondary to mesothelioma and carcinoma," Cancer Biology and Therapy, vol. 4, no. 3, pp. 342-346, 2005.

[11] D. Berd and M. J. Mastrangelo, "Active immunotherapy of human melanoma exploiting the immunopotentiating effects 
of cyclophosphamide," Cancer Investigation, vol. 6, no. 3, pp. 337-349, 1988.

[12] M. F. Mescher and J. D. Rogers, "Immunotherapy of established murine tumors with large multivalent immunogen and cyclophosphamide," Journal of Immunotherapy, vol. 19, no. 2, pp. 102-112, 1996.

[13] J.-Y. Liu, Y. Wu, X.-S. Zhang, et al., "Single administration of low dose cyclophosphamide augments the antitumor effect of dendritic cell vaccine," Cancer Immunology, Immunotherapy, vol. 56, no. 10, pp. 1597-1604, 2007.

[14] J. Taieb, N. Chaput, N. Schartz, et al., "Chemoimmunotherapy of tumors: cyclophosphamide synergizes with exosome based vaccines," Journal of Immunology, vol. 176, no. 5, pp. 2722 2729, 2006.

[15] R. H. Goldfarb, M. Ohashi, K. W. Brunson, et al., "Augmentation of IL-2 activated natural killer cell adoptive immunotherapy with cyclophosphamide," Anticancer Research, vol. 18, no. 3, pp. 1441-1446, 1998.

[16] E. Proietti, G. Greco, B. Garrone, et al., "Importance of cyclophosphamide-induced bystander effect on $\mathrm{T}$ cells for a successful tumor eradication in response to adoptive immunotherapy in mice," Journal of Clinical Investigation, vol. 101, no. 2, pp. 429-441, 1998.

[17] M. A. Mihalyo, A. D. H. Doody, J. P. McAleer, et al., "In vivo cyclophosphamide and IL-2 treatment impedes selfantigen-induced effector CD4 cell tolerization: implications for adoptive immunotherapy," Journal of Immunology, vol. 172, no. 9, pp. 5338-5345, 2004.

[18] L. Li, T. Okino, T. Sugie, et al., "Cyclophosphamide given after active specific immunization augments antitumor immunity by modulation of Th1 commitment of $\mathrm{CD} 4^{+} \mathrm{T}$ cells," Journal of Surgical Oncology, vol. 67, no. 4, pp. 221-227, 1998.

[19] I. F. Hermans, T. W. Chong, M. J. Palmowski, A. L. Harris, and V. Cerundolo, "Synergistic effect of metronomic dosing of cyclophosphamide combined with specific antitumor immunotherapy in a murine melanoma model," Cancer Research, vol. 63, no. 23, pp. 8408-8413, 2003.

[20] R. J. North, "Cyclophosphamide-facilitated adoptive immunotherapy of an established tumor depends on elimination of tumor-induced suppressor T cells," Journal of Experimental Medicine, vol. 155, no. 4, pp. 1063-1074, 1982.

[21] M. L. Salem, A. N. Kadima, S. A. El-Naggar, et al., "Defining the ability of cyclophosphamide preconditioning to enhance the antigen-specific CD ${ }^{+}$T-cell response to peptide vaccination: creation of a beneficial host microenvironment involving type I IFNs and myeloid cells," Journal of Immunotherapy, vol. 30, no. 1, pp. 40-53, 2007.

[22] A. K. Nowak, R. A. Lake, and B. W. S. Robinson, "Combined chemoimmunotherapy of solid tumours: improving vaccines?" Advanced Drug Delivery Reviews, vol. 58, no. 8, pp. 975-990, 2006.

[23] F. Ghiringhelli, C. Menard, P. E. Puig, et al., "Metronomic cyclophosphamide regimen selectively depletes $\mathrm{CD} 4{ }^{+} \mathrm{CD} 25^{+}$ regulatory $\mathrm{T}$ cells and restores $\mathrm{T}$ and $\mathrm{NK}$ effector functions in end stage cancer patients," Cancer Immunology, Immunotherapy, vol. 56, no. 5, pp. 641-648, 2007.

[24] Y. Motoyoshi, K. Kaminoda, O. Saitoh, et al., "Different mechanisms for anti-tumor effects of low- and high-dose cyclophosphamide," Oncology Reports, vol. 16, no. 1, pp. 141146, 2006.

[25] Y. Ikezawa, M. Nakazawa, C. Tamura, K. Takahashi, M. Minami, and Z. Ikezawa, "Cyclophosphamide decreases the number, percentage and the function of $\mathrm{CD} 25^{+} \mathrm{CD} 4^{+}$regulatory $\mathrm{T}$ cells, which suppress induction of contact hypersens- itivity," Journal of Dermatological Science, vol. 39, no. 2, pp. 105-112, 2005.

[26] M. E. C. Lutsiak, R. T. Semnani, R. De Pascalis, S. V. S. Kashmiri, J. Schlom, and H. Sabzevari, "Inhibition of $\mathrm{CD}^{+} 25^{+} \mathrm{T}$ regulatory cell function implicated in enhanced immune response by low-dose cyclophosphamide," Blood, vol. 105, no. 7, pp. 2862-2868, 2005.

[27] F. Ghiringhelli, N. Larmonier, E. Schmitt, et al., "CD $4^{+} \mathrm{CD} 25^{+}$ regulatory $\mathrm{T}$ cells suppress tumor immunity but are sensitive to cyclophosphamide which allows immunotherapy of established tumors to be curative," European Journal of Immunology, vol. 34, no. 2, pp. 336-344, 2004.

[28] R. G. van der Most, A. J. Currie, S. Mahendran, et al., "Tumor eradication after cyclophosphamide depends on concurrent depletion of regulatory $\mathrm{T}$ cells: a role for cycling TNFR2expressing effector-suppressor $\mathrm{T}$ cells in limiting effective chemotherapy," Cancer Immunology, Immunotherapy, vol. 58, no. 8, pp. 1219-1228, 2009.

[29] R. G. van der Most, A. J. Currie, S. Mahendran, et al., "Tumor eradication after cyclophosphamide depends on concurrent depletion of regulatory $\mathrm{T}$ cells: a role for cycling TNFR2expressing effector-suppressor $\mathrm{T}$ cells in limiting effective chemotherapy," Cancer Immunology, Immunotherapy, vol. 58, no. 8, pp. 1219-1228, 2009.

[30] C. Jackaman, S. Cornwall, A. M. Lew, Y. Zhan, B. W. S. Robinson, and D. J. Nelson, "Local effector failure in mesothelioma is not mediated by $\mathrm{CD} 4^{+} \mathrm{CD} 25^{+}$T-regulator cells," European Respiratory Journal, vol. 34, no. 1, pp. 162$175,2009$.

[31] M. R. Davis, L. S. Manning, D. Whitaker, M. J. Garlepp, and B. W. S. Robinson, "Establishment of a murine model of malignant mesothelioma," International Journal of Cancer, vol. 52, no. 6, pp. 881-886, 1992.

[32] M. B. Lutz, N. Kukutsch, A. L. J. Ogilvie, et al., "An advanced culture method for generating large quantities of highly pure dendritic cells from mouse bone marrow," Journal of Immunological Methods, vol. 223, no. 1, pp. 77-92, 1999.

[33] M. Miyara and S. Sakaguchi, "Natural regulatory T cells: mechanisms of suppression," Trends in Molecular Medicine, vol. 13, no. 3, pp. 108-116, 2007.

[34] S. Sakaguchi, "Regulatory T cells," Springer Seminars in Immunopathology, vol. 28, no. 1, pp. 1-2, 2006.

[35] T. Yamaguchi and S. Sakaguchi, "Regulatory T cells in immune surveillance and treatment of cancer," Seminars in Cancer Biology, vol. 16, no. 2, pp. 115-123, 2006.

[36] H. Nishikawa, T. Kato, I. Tawara, et al., "Definition of target antigens for naturally occurring $\mathrm{CD} 4{ }^{+} \mathrm{CD} 25^{+}$regulatory $\mathrm{T}$ cells," Journal of Experimental Medicine, vol. 201, no. 5, pp. 681-686, 2005.

[37] S. Sakaguchi, "Immunologic tolerance maintained by regulatory T cells: implications for autoimmunity, tumor immunity and transplantation tolerance," Vox Sanguinis, vol. 83, supplement 1, pp. 151-153, 2002.

[38] J.-P. H. Machiels, R. T. Reilly, L. A. Emens, et al., "Cyclophosphamide, doxorubicin, and paclitaxel enhance the antitumor immune response of granulocyte/macrophage-colony stimulating factor-secreting whole-cell vaccines in HER-2/neu tolerized mice," Cancer Research, vol. 61, no. 9, pp. 3689-3697, 2001.

[39] S. Wada, K. Yoshimura, E. L. Hipkiss, et al., "Cyclophosphamide augments antitumor immunity: studies in an autochthonous prostate cancer model," Cancer Research, vol. 69, no. 10, pp. 4309-4318, 2009. 
[40] F. Maesen and R. Willighagen, "Regression of a malignant tumour of the pleura," European Journal of Respiratory Diseases, vol. 71, no. 2, pp. 135-138, 1987.

[41] B. W. S. Robinson, C. Robinson, and R. A. Lake, "Localised spontaneous regression in mesothelioma-possible immunological mechanism," Lung Cancer, vol. 32, no. 2, pp. 197-201, 2001.

[42] E. Schwartz, C. Maayan, M. Mouallem, S. Engelberg, and E. Friedman, "Malignant peritoneal mesothelioma: longterm spontaneous clinical remission," Medical and Pediatric Oncology, vol. 19, no. 4, pp. 325-328, 1991.

[43] J. E. Pilling, A. G. Nicholson, C. Harmer, and P. Goldstraw, "Prolonged survival due to spontaneous regression and surgical excision of malignant mesothelioma," Annals of Thoracic Surgery, vol. 83, no. 1, pp. 314-315, 2007.

[44] H. Yanagawa, S. Sone, K. Fukuta, Y. Nishioka, and T. Ogura, "Local adoptive immunotherapy using lymphokineactivated killer cells and interleukin-2 against malignant pleural mesothelioma: report of two cases," Japanese Journal of Clinical Oncology, vol. 21, no. 5, pp. 377-383, 1991.

[45] H. Bielefeldt-Ohmann, A. L. Marzo, R. P. Himbeck, A. G. Jarnicki, B. W. S. Robinson, and D. R. Fitzpatrick, "Interleukin-6 involvement in mesothelioma pathobiology: inhibition by interferon $\alpha$ immunotherapy," Cancer Immunology Immunotherapy, vol. 40, no. 4, pp. 241-250, 1995.

[46] P. Astoul, D. Picat-Joossen, J.-R. Viallat, and C. Boutin, "Intrapleural administration of interleukin-2 for the treatment of patients with malignant pleural mesothelioma: a phase II study," Cancer, vol. 83, no. 10, pp. 2099-2104, 1998.

[47] I. Caminschi, E. Venetsanakos, C. C. Leong, M. J. Garlepp, B. W. S. Robinson, and B. Scott, "Cytokine gene therapy of mesothelioma: immune and antitumor effects of transfected interleukin-12," American Journal of Respiratory Cell and Molecular Biology, vol. 21, no. 3, pp. 347-356, 1999.

[48] R. J. Kruklitis, S. Singhal, P. Delong, et al., "Immuno-gene therapy with interferon- $\beta$ before surgical debulking delays recurrence and improves survival in a murine model of malignant mesothelioma," Journal of Thoracic and Cardiovascular Surgery, vol. 127, no. 1, pp. 123-130, 2004.

[49] C. Robinson, M. Callow, S. Stevenson, B. Scott, B. W. S. Robinson, and R. A. Lake, "Serologic responses in patients with malignant mesothelioma. Evidence for both public and private specificities," American Journal of Respiratory Cell and Molecular Biology, vol. 22, no. 5, pp. 550-556, 2000.

[50] J. Banchereau, F. Briere, C. Caux, et al., "Immunobiology of dendritic cells," Annual Review of Immunology, vol. 18, pp. 767-811, 2000.

[51] S. Nagaraj and D. I. Gabrilovich, "Tumor escape mechanism governed by myeloid-derived suppressor cells," Cancer Research, vol. 68, no. 8, pp. 2561-2563, 2008.

[52] W. J. Grossman, J. W. Verbsky, W. Barchet, M. Colonna, J. P. Atkinson, and T. J. Ley, "Human T regulatory cells can use the perforin pathway to cause autologous target cell death," Immunity, vol. 21, no. 4, pp. 589-601, 2004.

[53] X. Cao, S. F. Cai, T. A. Fehniger, et al., "Granzyme B and perforin are important for regulatory $\mathrm{T}$ cell-mediated suppression of tumor clearance," Immunity, vol. 27, no. 4, pp. 635-646, 2007.

[54] G. Darrasse-Jèze, A.-S. Bergot, A. Durgeau, et al., "Tumor emergence is sensed by self-specific CD44hi memory Tregs that create a dominant tolerogenic environment for tumors in mice," Journal of Clinical Investigation, vol. 119, no. 9, pp. 2648-2662, 2009.
[55] M. Awwad and R. J. North, "Cyclophosphamide-induced immunologically mediated regression of a cyclophosphamideresistant murine tumor: a consequence of eliminating precursor L3T4+ suppressor T-cells," Cancer Research, vol. 49, no. 7, pp. 1649-1654, 1989.

[56] A. M. Ercolini, B. H. Ladle, E. A. Manning, et al., "Recruitment of latent pools of high-avidity $\mathrm{CD}^{+} \mathrm{T}$ cells to the antitumor immune response," Journal of Experimental Medicine, vol. 201, no. 10, pp. 1591-1602, 2005.

[57] L. Xu, W. Xu, Z. Jiang, F. Zhang, Y. Chu, and S. Xiong, "Depletion of $\mathrm{CD} 4{ }^{+} \mathrm{CD} 25^{\text {high }}$ regulatory $\mathrm{T}$ cells from tumor infiltrating lymphocytes predominantly induces Th1 type immune response in vivo which inhibits tumor growth in adoptive immunotherapy," Cancer Biology and Therapy, vol. 8, no. 1, pp. 66-72, 2009.

[58] S. Hori and S. Sakaguchi, "Foxp3: a critical regulator of the development and function of regulatory T cells," Microbes and Infection, vol. 6, no. 8, pp. 745-751, 2004. 


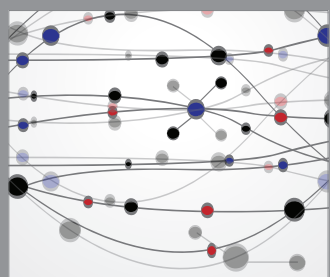

The Scientific World Journal
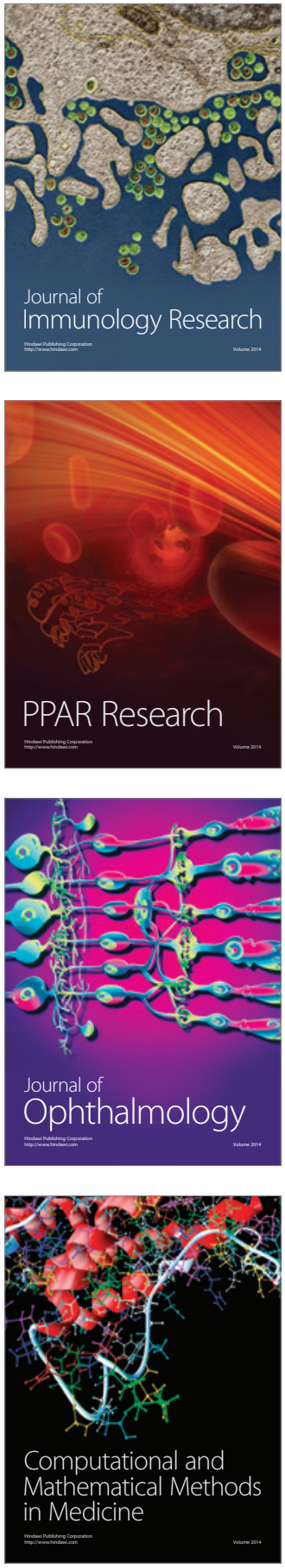

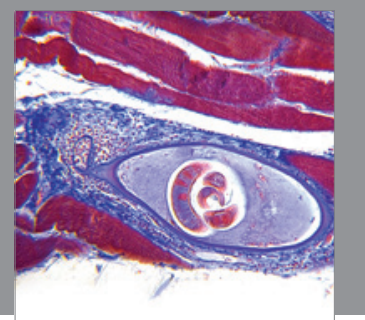

Gastroenterology

Research and Practice
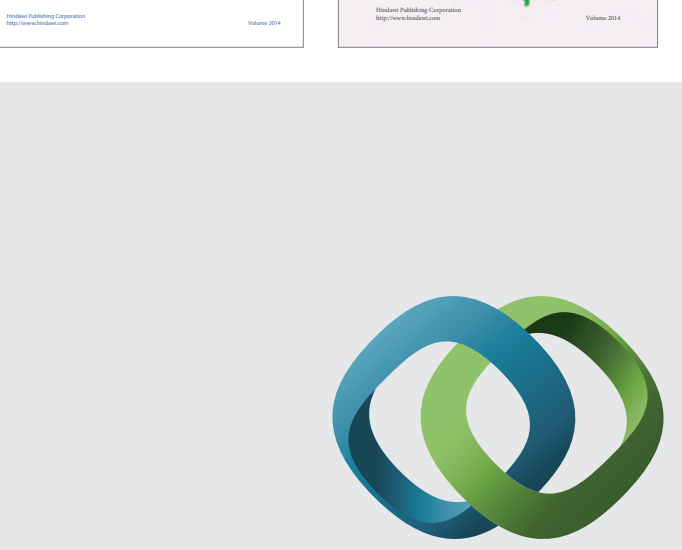

\section{Hindawi}

Submit your manuscripts at

http://www.hindawi.com
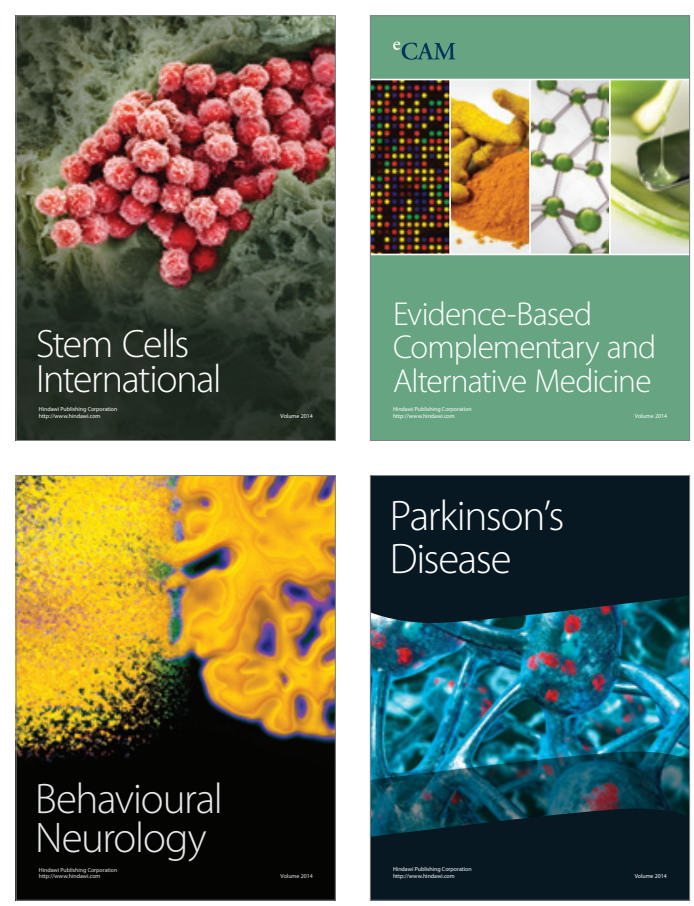

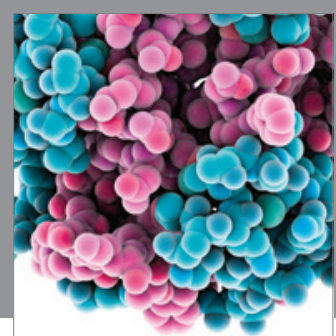

Journal of
Diabetes Research

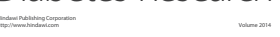

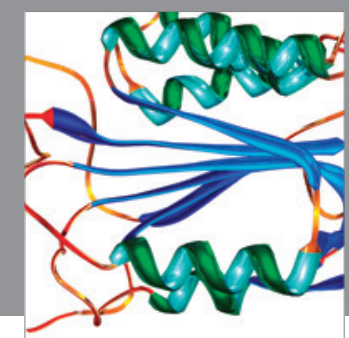

Disease Markers
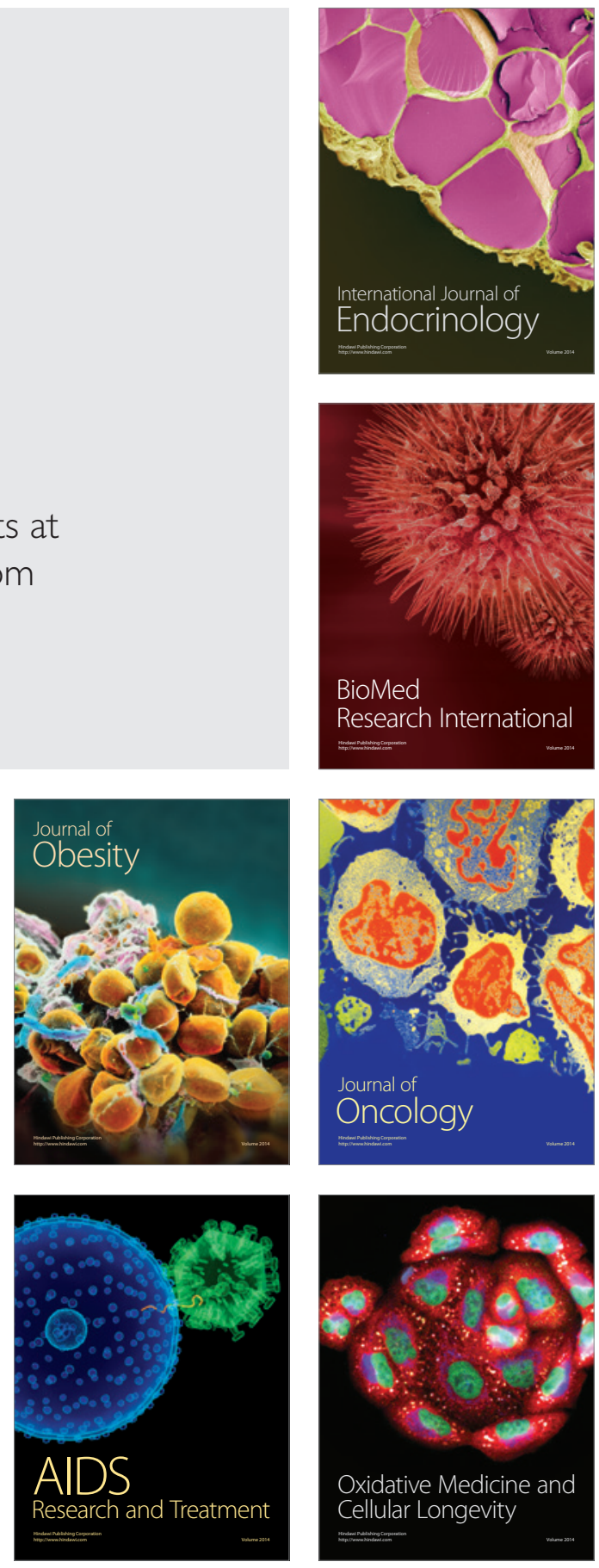